\title{
The Relationship of Insider Trading Announcements, Ownership Structure and Corporate Governance: An Event Study Analysis of Athens Stock Exchange Market Technology Firms
}

\author{
Ioannis Antoniadis ${ }^{1}$, Christos Gkasis ${ }^{2}$ \& Stamatis Kontsas ${ }^{3}$ \\ ${ }^{1}$ School of Economics, University of Western Macedonia, Kozani, Greece \\ ${ }^{2}$ National Bank of Greece, Greece \\ ${ }^{3}$ School of Economics, University of Western Macedonia, Grevena Greece \\ Correspondence: Ioannis Antoniadis, School of Economics, University of Western Macedonia, Koila Kozani, \\ 50100 Greece. Tel: 30-246-106-8000 ext. 1912. E-mail: iantoniadis@ teiwm.gr
}

Received: April 3, 2019

Accepted: May 14, 2019

Online Published: May 20, 2019

doi:10.5539/ijef.v11n7p13

URL: https://doi.org/10.5539/ijef.v11n7p13

\begin{abstract}
.
In the present paper, the relationship between corporate governance mechanisms of a firm and stock returns triggered by insider trading announcements is examined. Event study methodology has been used to evaluate the influence of 636 insider trading announcements performed by executives of 14 listed firms in the Athens Stock Exchange, that operate in the technology sector, during the period 2007-2013. The relationship between cumulative abnormal stock returns (CARs), caused by the announcements, and corporate governance characteristics, was then examined for different time windows, both for sales and purchases of stocks by insiders. Our findings suggest that insider trading, especially in purchases, performed by CEOs and members of the Boards of Directors, has a significant effect on stock returns in the long run. More specifically concentrated ownership structures and control were found to have a negative/positive effect in abnormal stock returns of the firms only in long-term periods of time following the announcement of purchases/sales.
\end{abstract}

Keywords: insider trading, corporate governance, stock returns, ownership structure, board of directors, technology sector, Greece

\section{Introduction}

Insider trading has been a well-known practice in capital markets around the world, and an important topic of debate for both academics, policy decision-makers and practitioners, as it is influencing the efficiency and transparency of markets' operation (Leland, 1992; Bainbridge, 1999; Du \& Wei, 2004; Fidrmuc et al., 2006). Insiders as executives, member of the board of Directors, and big shareholders (blockholders) of the firms have access to superior and exclusive information regarding financial data and outlook, everyday operation details of the firm, and long term strategic plans, compared to the rest of the shareholders. This access to exclusive information can be exploited by insiders in order to benefit from abnormal profits derived from their transactions on stocks of their firms (Seyhun, 1986; Bainbridge, 1999; Ravina \& Sapienza, 2010), compared to outsiders, in a ways characterized by relevant literature as unethical (Moore, 1990; Cinar, 1999) and harmful to shareholders' value and wealth (Hu \& Noe, 2001).

The fact that insiders are able to perform stock transactions based on private information, earning superior returns, compared to the rest of the shareholders, is widely acknowledged since the first years of operation of organized markets (Bainbridge, 1999; Fidrmuc et al., 2006; Antoniadis et al., 2015; Koudijs, 2015). In order to protect shareholders from that kind of opportunistic behavior special legislation has been introduced in most of the countries of the world (La Porta et al., 2002; Beny, 2004; Beny, 2006). Most countries legally prohibit insiders to perform any transaction (purchasing or selling), without disclosing the nature of these transactions to the public (Bainbridge, 1999; Maug, 2002; Betzer \& Theissen, 2009) in order to prevent patterns of unethical behavior and exploitation of shareholders by insiders. Insider trading regulation supporters argue that full disclosure of transactions performed by insiders benefit shareholders' wealth, and strengthen their trust in both the firm and the efficient and transparent operation of the market (Bainbridge, 1999; Hamill et al., 2002; Benny, 2004). 
Corporate governance is also suggested as a way of mitigating the negative effects of insider trading for both firms and markets. Relevant literature has presented proof that corporate governance can contribute substantially in controlling insiders and limiting the negative effects of insider trading (Shleifer \& Vishny, 1997; Bushman \& Smith, 2003), influencing the performance of firms and their investments' decision-making process (Demsetz \& Villalonga, 2001; Bebchuk \& Weisbach, 2010). A comprehensive corporate governance system with efficient internal mechanisms can avert insiders from decisions that are damaging to the firm performance and value (Bailey et al., 2006). Corporate Governance mechanisms such as ownership structure, controlling shareholders, institutional shareholders (Shleifer \& Vishny, 1997; Goergen \& Rennenbog, 2006) can restrict and prohibit abusive actions by effectively supervising and punishing accordingly under-performing managers (Demsetz \& Villalonga, 2001; Cziraki et al., 2014).

Notwithstanding the importance of the topic, for the efficient operation of both firms and capital markets, it has not been until recently that academic research has been conducted for other countries apart the ones of the Anglo-Saxon corporate governance system and more specifically the US and the UK (Leledakis et al., 2010; Thalassinos et al., 2012; Antoniadis et al., 2017). Little attention has been paid in countries and economies that are classified in the continental system of corporate governance, like Greece (Nerantzidis \& Filos, 2014).

In this paper, we examine the relationship of insider trading, with specific corporate governance mechanisms, as are identified by relevant literature. The effect that ownership structure, separation of ownership and control, members of the board of directors, has on abnormal returns are being surveyed along with the effective control variables, related to the transaction and the firm value. In total, a number of 636 announcements of insider trading for the 14 technology sector firms listed in Athens Stock Exchange Market (ATHEX), that operate in software, hardware, and telecommunications) firms, during the period 2007-2013, are examined. Event study methodology with the appropriate statistical tests is used in order to estimate Cumulative Abnormal Returns (CAR) for every announcement for various event windows. Afterward, OLS regression is performed to assess the link between the abnormal returns produced by insider trading, determined by CAR, and corporate governance and ownership variables described above for both Sales and purchases subsamples, and Chow-tests are performed to test for structural stability of our model.

Our paper adds to the relevant literature on corporate governance in numerous ways. First of all, our work extends the limited work performed on the subject for Greece (Lekkas, 1998; Leledakis et al., 2010; Thalassinos et al., 2012; Antoniadis et al., 2017, 2019). Second, our survey focuses on one sector, and by comparing it with similar studies, can provide evidence of different insider behavior in different sectors. And finally, the period examined encompasses a transitional period of time for the Greek economy and stock market with the outburst of the financial crisis of 2010. Furthermore, and to the best of our knowledge, there is no published paper, providing relevant evidence, examining the link of insider trading, corporate governance and ownership structure for the Greek Stock market.

The remainder of the paper is structured as follows. Section 2 reviews the legal framework and status of Corporate Governance in Greece, followed by an analysis and discussion of the literature on the relationship of insider trading and ownership structure and corporate governance, and the development of the hypotheses that will be tested, in Section 3. The following section presents the methodology employed in our research, the characteristics of the sample of firms examined and the variables used. Section 5 presents the empirical results of the econometric analysis, and a brief discussion is the results is offered. Finally, Section 6 concludes the paper, summarizing our main findings and proposing future research directions.

\section{Corporate Governance and Insider Trading Regulation in Greece}

Corporate Governance still remains an important and growing subject $\mathrm{f}$ practice and research around the world (Kostyuk et al., 2018). Corporate Governance and the discussion of imposing a framework that listed firms would apply in their governance emerged as a topic of discussion in Greece during the mid-1990s through the initiative of Athens Stock Exchange in 1998 (Nerantzidis \& Filos, 2014).

Greece can be sorted in the Continental system of Corporate Governance (Travlos, 2001; Nerantzidis \& Tsamis, 2017), that is characterized by high levels of ownership concentration and family ownership, weak investor protection, limited development of capital markets, and inactive institutional investors (La Porta et al., 2002).

Legal framework, concerning insider trading, was mainly introduced in Greece, long after 1989 as a result of the integration of European Union legislation that made mandatory for all its members to apply the European Community Insider Trading Directive (89 592 EEC of November 13, 1989), by incorporating it in the Greek national law. Before that time Lekkas (1998) characterized the framework as inadequate and "dark", where insider trading was not simply a common practice but the status quo and modus operandi of the listed firms in 
ATHEX. It must be commented that a lot of progress has been made since then and Corporate governance reporting in Greece has improved substantially during the last two decades (Nerantzidis \& Tsamis, 2017). The main characteristics and features of the legal framework of corporate governance in Greece were laid out in 2002 (Spanos, 2005).

In 2011, the European Commission announced a set of proposals for a new regulatory framework that would update and expand its current legal framework on insider trading and market manipulation (Langenbucher, 2013). These changes also mitigated in Greece. In a recent survey on the status of the Corporate Governance framework in Greece Nerantzidis and Filos (2014) point out the remarkable enhancement of the legal and institutional framework of corporate governance in Greece through the incorporation of a big number of European Directives in the the Greek Law system, resulting to an increase in transparency, disclosure and protection of the rights of small investors (outsiders).

The current framework for transactions notifications obligation that firms are currently operating with according to the Hellenic Capital Market Commission is in line with Article 18 of the Regulation (EU) No. 596/2014 of 16 April 2014, and the Commission Implementing Regulation (EU) 2016/347 of 10 March 2016, entered in force in July 3, 2016.

As our sample covers the period 2007 to 2013, the above directive does not apply to our study. For the period of time, we examine the Law 3340/2015 applies. Every company listed in ATHEX according to this law must present a list of employees, under contract or otherwise, who have access to insider information, and make that list available to the Hellenic Capital Market Commission (HCMC). Disclosure requirements require that insiders must notify their company and relevant authorities of the transaction the day after its execution. Afterward, the appropriate authority notifies the public, no later than two calendar day after receiving the information. Insiders are defined as a) members of the administrative, management or supervisory body of that entity or b) senior executives who are not a member of the mentioned above bodies, but who have systematic access to inside information relating directly or indirectly to that entity, and power to take managerial decisions affecting the future developments and business prospects of that entity (Law 3340/2005, 2005). These obligations concern also the persons that are closely related to the ones who hold managerial responsibilities and positions within the firm. This obligation also covers all shareholders who are in possession of more than $5 \%$ of the voting rights of the company.

\section{Literature Review and Hypothesis Development}

Insider trading has been a major focus for legal scholars and regulators around the world. Bainbridge (1999) summarised the 3 main arguments of the supporters of insider trading regulation. First insider trading damages investors and thus weakens investor confidence in the securities markets, leading to underdevelopment and the inefficient operation of markets. Second insider trading damages the issuer of the affected securities and finally, insider trading equals to the theft of property of the firm, and its shareholders.

"Insider trading" is usually perceived by investors as a negative, and unethical action undertaken by managers of firms that are associated with illegal conduct. However, this term and course of action embodies includes legal conduct as well. The legal version is when corporate insiders - officers, directors, and employees - buy and sell stock in their own companies, while illegal insider trading refers to buying or selling a security, in breach of a fiduciary duty or other relationship of trust and confidence (SEC, 2017). This illegal conduct comes as a result of the possession of substantial, non-publicly available information about the firms' traded securities, that is used by managers (insiders) to gain abnormal profits at the expense of shareholders (outsiders). Insider trading violations may also involve leaking such crucial information, securities trading by the person who came in possession of that information, and securities trading by those who misappropriate such information.

Leland (1992) summarises the pro and against arguments concerning insider trading. The arguments for insider trading is the import of new information by insider transactions in the market, that will lead to better asset valuation and therefore to reducing investment risks. As a result, more investments will occur. Lizarzabaru et al. (2014), also reviewed a part of literature that present insider trading as a part of an implicit compensation scheme (Jackson et al., 2008). On the other hand, outside investors may be deterred to invest in a market they believe is unfair, resulting in reduced liquidity and increased volatility (Beny, 2004; Du \& Wei, 2004).

Hamill et al (2002) identify two main reasons, that lead insiders to perform these transactions: a) liquidity reasons, or b) the possession of vital non-disclosed information. Under the Efficient Market Hypothesis (EMH) there would be no substantial market reaction in the first case. However, in the second case, the insiders' purpose could be either earning short-term profits by this transaction or signaling the market for information concerning the firm, industry or market developments, that may have an effect on firm's value. So, if insiders sell/buy their 
stocks due to the possession of information, they communicate a negative/positive signal to the market as this transaction must be founded on information that would result to an expected decrease/increase of the value of the firm. These kinds of insider trading transactions should bring abnormal returns to insiders at the cost of shareholders' wealth (Bainbridge, 2000; Hamill et al., 2002) which violates the principle of equal treatment of shareholders (Beny, 2006; Betzer \& Theissen 2009). That is more important for the CEO of the firm, whose actions are scrutinously monitored, and his transactions are considered to act as a signal for the future performance of the firm by outsiders (Hamill et al., 2002; Jeng et al., 2003; Adams \& Ferreira, 2005).

Insider trading is fundamentally connected with corporate governance (Arshadi \& Eyssell 1995; Fidrmuc et al., 2006; Betzer \& Theissen; 2008). Literature provides a number of Corporate Governance definitions based on different economics theories. The most well-known definition of corporate governance is the one provided by Shleifer and Vishny (1997) defining corporate governance as "the ways in which suppliers of finance to corporations assure themselves of getting a return on their investment". Goergen and Renneboog (2006), following the agency theory, extend this definition by describing corporate governance as "the combination of mechanisms which ensure that the management (agents) runs the firm for the benefit of one or several stakeholders (principals)". The inclusion of stakeholders that includes shareholders, creditors, suppliers, clients, employees and other parties with whom the firm conducts its business, extends the scope and strategic importance of corporate governance.

The most accepted theory explaining the necessity of corporate governance is agency theory (Shleifer \& Vishny, 1997). That is significant as far as insider trading is concerned as it is commonly accepted to be a typical expression of agency problem and asymmetric information between managers -agents (insiders) and shareholders - principals (outsiders) that can result to significant wealth expropriation of the latter (Beny, 2004, 2006). Bailey et al. (2006) conclude that better corporate governance provides an institutional framework that improves significantly the accuracy and transparency of disclosed information to shareholders including the ones concerning insider trading. This is achieved by a) limiting the opportunistic and unethical transactions by insiders and b) decreasing the leakage of information to insiders before the public announcement (Bajo et al., 2009).

Despite the fact that implementing a comprehensive and rigorous corporate governance framework, has been found to reduce agency costs, and benefit substantially firms that implement it (Lizarzaburu et al., 2014), there is little empirical evidence on the ways it would successfully limit profitable insider trading at the expense of the shareholders, in the presence of separation of ownership and control.

One of the most important corporate governance mechanism is ownership structure and most specifically the existence of blockholders (Agrawal \& Knoeber, 1996; Shleifer \& Vishny, 1997; Kostyuk et al., 2018), as they have incentives to actively monitor managers and other insiders, thus ameliorating the main causes of the agency problem, related with the separation of ownership and control and the existence of insiders. An increase in the number of shares shareholders own should increase their motivation for more effective and efficient monitoring of the insiders (Bhide, 1993). This relation has also been validated by Morck et al. (2000), as they have reported the existence of a positive relationship between ownership concentration and firm performance as measured in firm value. In a similar fashion, Thomsen and Pedersen (2000), argued that the existence of blockholders has a positive relationship with the growth of turnover and market to book value (MV/BV) ratio of the firm, that can also be used as a proxy for its value. Demsetz and Villalonga (2001) have not found performance to be affected by ownership both managerial or blockholders. However, following the same methodology, Kapopoulos and Lazaretou (2007), in their paper, examined 175 Greek firms listed in ATHEX, reported a positive relationship between ownership concentration and firm profitability measured by Tobin's $Q$ and the accounting profit rate. a A positive relationship between ownership concentration and return on assets is also reported by Alimehmeti and Paletta (2012), who examined 175 Italian firms for the period 2006-2009, with the exception of 2008, where a non-linear relationship was found, possibly due to the financial crisis, enhancing expropriation effects by insiders of the firms.

Fidrmuc et al. (2006) also examined the relationship of the ownership structure of a firm and insider trading, and more specifically the role of blockholders as an effective mechanism for controlling insider trading. They propose that large shareholders have stronger incentives, as they own a greater stake in the company, to actively and efficiently monitor and control insiders' actions, through the larger voting power they possess. That is also true in the cases where the blockholder is also the CEO of the firm (Adams et al., 2005). Abnormal returns after insider purchases were found to be smaller in the presence of blockholders and more concentrated ownership structures, as large shareholders are more motivated, to monitor not only managers but also other shareholders that may have access to insider information. As a result of this intensive monitoring, insider trades are less 
informative in these firms (Hamill et al., 2002). In their research of small capitalized firms in the United Kingdom found that investors react positively to the information signals of directors' equity purchases, providing support for the information content rationale of insider trading. But the same was not valid for directors' equity sales Their results suggest that a positive association between financial performance and the type of trade directors engage in is present. In the case of sales, the hypothesis of liquidity is mostly supported.

This relationship is also reported by Fidrmuc et al. (2006), who compared insider trading in the United States and the United Kingdom, and found that the positive reaction of stock prices in buying transaction is bigger in the presence of institutional shareholders in the firms compared to the ones with individual shareholders. Dai et al. (2013) find that compared with insiders of ill-governed firms, those of better-governed firms earn significantly smaller abnormal profits. The information content hypothesis is also supported by the research of von Koch et al. (2013) who found that firms with rigorous corporate governance rules and mechanisms are regarded by the market as trustworthy, resulting to positive market reactions on insider trading. Cziraki et al. (2014) also offer additional insight into the ways that good corporate governance affects insider trading, namely through increased shareholder awareness of the firms' situation and increased monitoring by blockholders. However, as Lambe (2014), points out no matter how scrutinous the legal framework may be, insider trading still occurs where there are opportunities for abnormal returns for insiders.

The position and the authority an insider holds within the firm plays a crucial role on the impact that insider trading has on stock returns (Seyhun, 1986), as members of the board may hold superior information compared to that to the management of the firm, the blockholders and the rest of the shareholders are able to obtain (Moore, 1990; Gregory et al., 2009; Nwafor 2014; Tsene, 2017).

Literature also identifies a number of control variables concerning the financial characteristics of the firm that have an impact on insider trading. For example, Dickgiesser and Kaserer (2009) found that the size of the firm affects negatively the abnormal returns of insider trading in periods bigger than 10 days after the stock purchases announcement. Shleifer and Vishny (1997), outlined the importance of capital structure and debt as corporate governance mechanisms, while Jiraporn et al. (2012) reported that for firms with lower standards of corporate governance, leverage can reduce agency cost, acting as an alternative mechanism of corporate governance.

The role of leverage as a mechanism that has the potential to control insider trading is not supported unanimously (Dhaliwal et al., 2006; Penman et al., 2007). The same stands for the relationship between ownership structure and insider trading as it was found by He and Rui (2016), in recent research in China, where the existence of a significant relationship between ownership structure and market reaction to insider sales, was not documented. Finally, another control variable reported by relevant literature is the value of the transaction (Dickgiesser \& Kaserer, 2009). Gregory et al. (2009) found this variable to have a positive/negative effect in the abnormal returns when it relates to buying/selling shares.

Corporate Governance in Greece appeared as an issue in the early 1990s but was formally introduced in April 1999, when the OECD published the Principles of Corporate Governance to their members, that would be the basis for the Blue Book on Corporate Governance that would be the basis for the Greek corporate governance framework (Spanos, 2005; Nerantzidis \& Filos, 2014). This reform was in order since the framework for investors' protection from insiders was beyond inadequate, leading to extreme cases of shareholders' wealth expropriation (Lekkas, 1998).

Insider trading has not been sufficiently examined in the Greek Stock Market. Leledakis et al. (2010) employed event study methodology to investigate the response of market prices to insider trading announcements. Their findings reveal the presence of agency problem since the effect of insider trading announcement is greater in widely held firms than in those with concentrated ownership structure. Moreover, the position that the person who performs the transaction has in the firm, is important. Thalassinos et al. (2012) examined insider trading in Greece from a technical point of view, by developing a platform that would help monitor insider trading announcements and stock prices reactions to the event with the use of event study methodology. Antoniadis et al. (2015) also examined the effect of insider trading in the firms of the technology sector in the Greek Stock Exchange Market. Their findings indicate that buying transactions do not affect abnormal stock returns while selling transactions have a positive effect before the announcement and negative afterward. Antoniadis et al. (2017, 2019), also found that there has been a change in the patterns of trading by insiders as a result of the financial crisis in Greece after 2010, and especially for the period following the transaction.

Our work will contribute to the ongoing discussion in the literature on insider trading by further investigating the relationship between insider trading and corporate governance in an economic environment under extreme financial crisis, exploring the behavior of insiders and the ways that corporate governance can provide a more 
transparent environment for shareholders in harsh economic periods.

\section{Methodology and Hypotheses}

In order to evaluate the effect, insider trading announcements have to the stock returns and the relationships developed with corporate governance the event study methodology is used. Event studies survey the outcome of defined events in the reactions of the stock prices before and after the event, offering insight concerning the presence of agency problem and agency cost (Shleifer \& Vishny, 1997). The examined announcements may concern purchasing and selling of securities by persons like the ones described in the previous section of the paper, not including transactions performed by shareholders like corporations or other organizations. The event study methodology is employed (Brown \& Warner, 1985; Campbell, 1997: pp. 149-168; McKinlay, 1997; Kennedy, 2008) to measure the effect of the announcement in stock returns by calculating the abnormal returns that the event has on a specific time window around the event and Cumulative Abnormal Returns for a period of time close to the event.

The rationale in this test lies in the efficient market hypothesis, where investors take under consideration any available information that would influence the returns of securities in an abnormal way compared to the one predicted by the CAPM model (equation 1).

$$
R_{i}=a_{i}+b_{i} \cdot R_{m t}+\varepsilon_{i},
$$

where at time $t: R_{i t}$ is the actual return of the stock i, $R_{m t}$ is the return of the market, $\alpha_{i, \text { and }} b_{i}$ are the coefficients of the OLS model and $\varepsilon_{i t}$ is the zero disturbance term with $E\left(\varepsilon_{i t}\right)=0$ and $\operatorname{Var}\left(\varepsilon_{i t}\right)=\sigma_{\varepsilon i t}{ }^{2}$.

The following step is to calculate, Abnormal Returns $\left(A R_{i t}\right)$, as the difference of expected return for time $t$, and actual returns of the stock $i$ for time $t$ as follows in equation (2):

$$
A R_{i t}=R_{i t}-\hat{R}_{i t}=R_{i t}-\left(\hat{a}+\hat{b} \cdot R_{m t}\right)
$$

where, $\widehat{a}, \hat{b}$, are the estimates for the coefficients $\alpha_{i} b_{i}$,

In order to measure the abnormal returns insiders, have for a specific time period, before and after the announcement, Cumulative Abnormal Returns (CAR) of every event are estimated, using the beta coefficient for the return of each firm's stock return in relation to the market returns of the General Index of the stock market. In our case that was done by using the returns of technology sector firms and the returns of the General index of ATHEX, using the OLS method for the equation (1), for an estimation window of 160 days [-180, -21] before the announcement (event) took place. Cumulative abnormal returns $(C A R)$ are then calculated as the sum of all abnormal returns for each firm $\left(\mathrm{AR}_{\mathrm{it}}\right)$ during the event window where $t \in\left[t_{1}, t_{2}\right]$.

$$
C A R_{i,\left(-t_{1}, t_{2}\right)}=\sum_{t=-t_{1}}^{t_{2}} A R_{i t}
$$

The event window is fixed around the day $t=0$, when the announcement of the transaction is being made, and a number of time periods (event windows) were then calculated for a time frame $\left[-t_{1}, t_{2}\right]$ that was set to $[-20,+20]$ days according to the literature (Campbell, 1997: pp. 149-168). More specifically CARs for 6 different event windows were estimated, covering both short-term periods of time before and after the event and long term periods after the event, that was found to be statistically significant.

The sample used for our study consists of the announcements concerning insider trading transactions for 14 technology firms (computer software/hardware and telecommunications) of the ATHEX during the period 2007-2013. The data concerning the announcements ownership structure, board composition, and control variables were collected from the ATHEX web page (www.helex.gr), and the investor relations section of the corporate websites of the examined firms while stock prices and market index data was collected by the Bloomberg database. The total sample of consists of 636 announcements (events) with 498 of them are purchases of shares and 138 selling of shares, after the exclusion of non-statistical important events and outliers.

The model that we are going to estimate is shown in equation (4), including variables that are presented and used in the relevant literature (Antoniadis et al., 2017, 2019). As a dependent variable we are going to use the effect that insider trading to the stock prices measured by CAR, and as independent variables 3 sets of corporate governance variables related to ownership structure, the identity and the capacity of the insiders, and financial characteristics of the firms, as were identified by relevant literature in Section 2. To estimate (4) OLS is going to be used, for announcements regarding purchases, and sales separately, and a pooled sample to test for structural stability of the regression using the appropriate Chow tests (Brooks, 2008; Kennedy, 2008).

$$
\begin{gathered}
C A R\left(\tau_{1}, \tau_{2}\right)_{i}=a+\beta_{1} C_{E O_{i}}+\beta_{2} \text { BOD }_{M E M}+\beta_{3} \text { BOD }_{N X C_{i}}+\beta_{4} \text { TRNVOL }_{i}+\beta_{5} O W N_{C O N T}+ \\
\beta_{6} \text { BLOCK }_{i}+\beta_{7} \text { OWNCONC }_{i}+\beta_{8} \text { LNCAP }_{i}+\beta_{9} L N M B V_{i}+\beta_{10} L N T A B V_{i}+u_{i}
\end{gathered}
$$


where $\left(\tau_{1}\right.$ and $\left.\tau_{2}\right)$ are the event windows $(-2,0),(-1,0),(0,+1),(0,+2),(0,+10)$ and $(0,+20), i$ are the observation of our sample, $\alpha$ is the constant term of the regression, $\beta_{1 \ldots 10}$ the estimated coefficients of the independent variables, and finally $u_{i}$ the disturbance term.

In Table 1 the variable definitions of our model are presented. Our variables are grouped in three main categories, that describe: a) the characteristics of the transactions performed such as the person performing the transaction, and the value of the transaction, b) the ownership structure and the separation of ownership and control of the firm, and c) the control variables.

Table 1. Variables definition

\begin{tabular}{|c|c|}
\hline Variable & Definition \\
\hline & Insiders position in the firm variables \\
\hline CEO & $=1$ if the person performing the transaction is the CEO, and 0 if otherwise (dummy variable) \\
\hline BOD_MEM & $=1$ if the person performing the transaction sits in the $\mathrm{BoD}$, and 0 if otherwise (dummy variable) \\
\hline BOD_NXC & $\begin{array}{l}=1 \text { if the person performing the transaction sits in the } \mathrm{BoD} \text { as a nonexecutive member, and } 0 \text { if otherwise } \\
\text { (dummy variable) }\end{array}$ \\
\hline TRNVOL & $\begin{array}{l}\text { Transaction value divided by the mean capitalization value of the equity during the period } \mathrm{t}=-180 \text { to } \mathrm{t}=-21 \\
\text { B. Ownership Structure variables }\end{array}$ \\
\hline OWN_CONTR & $=1$ if separation of ownership and control is not present 0 if otherwise (dummy variable) \\
\hline BLOCK & The percentage of shares owned by the largest blockholder. \\
\hline \multirow[t]{2}{*}{ OWNCONC } & $\begin{array}{l}\text { Ownership concentration measured as the sum of the percentage of shares owned by the largest } 5 \\
\text { shareholders }\end{array}$ \\
\hline & C. Control variables \\
\hline LNCAP & The logarithm of the average capitalization during the period $t=-180$ to $t=-21$ \\
\hline LNMBV & The logarithm of the average market-to-book value during the period $t=-180$ to $t=-21$ \\
\hline LNTABV & The logarithm of the ratio of Total Assets to Book Value \\
\hline
\end{tabular}

Gregory et al. (2006) and Dickgiesser and Kaserer (2009) propose that if an insider holds a position in the Board of Director, that should have affected positively abnormal returns. The TRNVOL variable is used to capture the effect that the volume of the transaction has on abnormal returns, and to screen the incentives of the performed transaction, whether informative or liquidity seeking. The ownership structure variables $B L O C K$ and $O W N C O N C$ examine the relationship between ownership structure and abnormal returns, and tests the monitoring hypothesis through diminished agency costs as a result of the existence of blockholders (Adams et al., 2005; Fidrmuc et al., 2006; Betzer \& Theissen, 2009; Antoniadis et al., 2019). Finally, the ownership and control separation issue is included in our model with the $O W N \_C O N T$ variable, shedding light in the nature of the agency problem faced by Greek firms.

Last but not least, in order to incorporate to our model, the market financial characteristics of the firms of the sample, 3 control variables are introduced, and more specifically the capitalization of the firm $(L N C A P)$, the market to book value ratio of the firm $(L N M B V)$, and the financial leverage of the firm measured by $L N T A B V$ (Fama and French, 1992; Dickgiesser and Kaserer, 2009). The empirical results derived from the estimation of the above model are presented in the following section.

\section{Empirical Results}

In Table 2 the main descriptive statistics are reported for the cross-sectional regression sample consisting of a total of 636 observations are presented, broken down in 3 panels. Panel A reports purchases, Panel B sales trading announcements, while Panel $\mathrm{C}$ presents the statistics for the whole sample. Buying transactions are mostly performed by the Board of Directors members, compared to sales trades. Selling trades volume is bigger compared to purchases. Ownership concentration is also found to be greater as far as buying trades are concerned, but when we control for the case of separation of ownership and control, it is higher in purchase announcements. 
Table 2. Descriptive statistics of control variables for the insiders transactions

\begin{tabular}{|c|c|c|c|c|c|}
\hline \multicolumn{6}{|c|}{ Panel A. Insider Purchases (number of observations 498) } \\
\hline & Mean & Std. Dev. & Skewness & Kurtosis & Jarque-Bera \\
\hline CEO & 0.7028 & 0.4575 & -0.8875 & 17.877 & 95.87 \\
\hline BOD_MEM & 0.9317 & 0.2525 & -34.235 & 127.203 & 2933.35 \\
\hline BOD_NXC & 0.1426 & 0.3500 & 20.446 & 51.804 & 445.61 \\
\hline TRNVOL & 0.0009 & 0.0027 & 100.028 & 1.371 .386 & 381663.00 \\
\hline OWN_CONT & 0.7410 & 0.4385 & -11.000 & 22.101 & 113.38 \\
\hline BLOCK & 0.4301 & 0.1930 & -0.1851 & 17.250 & 36.57 \\
\hline OWNCONC & 0.7347 & 0.1128 & -0.4392 & 31.836 & 16.70 \\
\hline LNCAP & 172.997 & 13.211 & 12.889 & 46.851 & 196.79 \\
\hline LNMBV & -0.2554 & 0.9326 & -13.600 & 75.964 & 591.90 \\
\hline LNTABV & 0.6222 & 0.4061 & 13.494 & 47.353 & 213.61 \\
\hline \multicolumn{6}{|c|}{ Panel B Insider Sales (number of observations 138) } \\
\hline & Mean & Std. Dev. & Skewness & Kurtosis & Jarque-Bera \\
\hline CEO & 0.3333 & 0.4731 & 0.7071 & 15.000 & 24.43 \\
\hline BOD_MEM & 0.8841 & 0.3213 & -23.992 & 67.561 & 213.51 \\
\hline BOD_NXC & 0.1087 & 0.3124 & 25.143 & 73.220 & 252.81 \\
\hline TRNVOL & 0.0027 & 0.0078 & 78.191 & 755.010 & 31630.45 \\
\hline OWN_CONT & 0.5580 & 0.4984 & -0.2335 & 10.545 & 23.01 \\
\hline BLOCK & 0.3922 & 0.1983 & 0.3512 & 14.798 & 16.12 \\
\hline OWNCONC & 0.6392 & 0.1780 & 0.1336 & 13.062 & 16.90 \\
\hline LNCAP & 191.954 & 20.098 & -0.0886 & 12.379 & 18.03 \\
\hline LNMBV & -0.9095 & 0.9560 & 0.4655 & 26.263 & 5.78 \\
\hline LNTABV & 0.6664 & 0.3874 & 20.023 & 136.120 & 739.73 \\
\hline \multicolumn{6}{|c|}{ Panel C. Pooled Data } \\
\hline & Mean & Std. Dev. & Skewness & Kurtosis & Jarque-Bera \\
\hline CEO & 0.6226 & 0.4851 & -0.5060 & 1.2561 & 107.7375 \\
\hline BOD_MEM & 0.9214 & 0.2694 & -3.1313 & 10.8053 & 2653.8260 \\
\hline BOD_NXC & 0.1352 & 0.3422 & 2.1335 & 5.5517 & 655.0293 \\
\hline TRNVOL & 0.7013 & 0.4581 & -0.8794 & 1.7734 & 121.8500 \\
\hline OWN_CONT & 0.0013 & 0.0044 & 11.8207 & 189.1294 & 932881.3000 \\
\hline BLOCK & 0.4219 & 0.1946 & -0.0669 & 1.6139 & 51.3869 \\
\hline OWNCONC & 0.5777 & 0.1252 & -0.6941 & 2.4412 & 59.3365 \\
\hline LNCAP & 17.7110 & 1.6879 & 1.0448 & 3.0499 & 115.7693 \\
\hline LNMBV & -0.3973 & 0.9751 & -0.8801 & 5.2054 & 210.9967 \\
\hline LNTABV & 0.6318 & 0.4023 & 1.4663 & 6.4023 & 534.6430 \\
\hline
\end{tabular}

In the following tables, the results of the regression estimation for equation (4) are estimated and presented for the announcements of insider trading concerning purchases, sales, and finally the pooled sample of transactions. In order to examine for structural stability of the model, Chow tests are performed and reported in Table 5. It must be noted that in all 3 cases the model seems to have better explanatory power for CARs in long periods of time after the announcement $(0,+10),(0+20)$. All 18 estimated regressions are statistical important since the $\mathrm{F}$ value exceeds the critical value.

In Table 3 the results for the purchases transactions are presented. When purchase transactions are executed by CEOs, the dependent variable CAR is positively and statistically significant affected, for the long term periods ( 0 , $+10),(0,+20)$ by $+0.043 \kappa \alpha 1+0.042$ respectively, as predicted by the relevant literature. However, when the announced buying transactions are performed by members of the Board of Directors, then CARs are negatively and statistically, significantly affected for the event windows $(0,+10),(0,+20),-0.059$ and -0.057 respectively. In the cases where non-executive members purchase stocks, these events affect CARs positively, stock prices for short periods of time, namely one day before the announcement $(+0.016)$ and one day after the announcement $(+0.020)$. The absence of separation of ownership and control has a positive effect on abnormal returns before the announcement of purchases and a negative effect in the long term after. The percentage of the main blockholder have a significant positive effect on stock returns only one day before the announcement, while the percentage held by the 5 biggest shareholders have a negative effect in the long term after the announcement. 
These results may provide evidence for the liquidity hypothesis, or considering the fact that ATHEX has mainly been "bearish" this period of time, as a market trade pattern by the owners of the firm to provide "support" to the stock price of the firm.

Table 3. OLS results for purchase announcements (498 observations)

\begin{tabular}{|c|c|c|c|c|c|c|}
\hline & $\begin{array}{l}\text { CAR } \\
(-2,0) \\
\end{array}$ & $\begin{array}{l}\text { CAR } \\
(-1,0) \\
\end{array}$ & $\begin{array}{l}\text { CAR } \\
(0,+1) \\
\end{array}$ & $\begin{array}{l}\text { CAR } \\
(0,+2) \\
\end{array}$ & $\begin{array}{c}\text { CAR } \\
(0,+10) \\
\end{array}$ & $\begin{array}{c}\text { CAR } \\
(0,+20) \\
\end{array}$ \\
\hline Constant & $\begin{array}{c}-0.034 \\
(-0.602)\end{array}$ & $\begin{array}{c}-0.012 \\
(-0.276)\end{array}$ & $\begin{array}{l}0.072 * \\
(1.759)\end{array}$ & $\begin{array}{c}0.124 * * \\
(2.368)\end{array}$ & $\begin{array}{c}0.375 * * * \\
(4.115)\end{array}$ & $\begin{array}{c}0.432 * * * \\
(3.591)\end{array}$ \\
\hline CEO & $\begin{array}{c}0.003 \\
(0.259)\end{array}$ & $\begin{array}{c}-0.003 \\
(-0.465)\end{array}$ & $\begin{array}{c}0.008 \\
(1.048)\end{array}$ & $\begin{array}{c}0.006 \\
(0.622)\end{array}$ & $\begin{array}{c}0.043 * * * \\
(2.624)\end{array}$ & $\begin{array}{c}0.042 * * \\
(1.943)\end{array}$ \\
\hline BOD_MEM & $\begin{array}{c}0.004 \\
(0.401)\end{array}$ & $\begin{array}{c}0.010 \\
(1.044)\end{array}$ & $\begin{array}{c}-0.006 \\
(-0.694)\end{array}$ & $\begin{array}{c}-0.013 \\
(-1.133)\end{array}$ & $\begin{array}{c}-0.059 * * * \\
(-2.903)\end{array}$ & $\begin{array}{c}-0.057 * * \\
(-2.143)\end{array}$ \\
\hline BOD_NXC & $\begin{array}{c}0.018 \\
(1.576)\end{array}$ & $\begin{array}{l}0.016^{*} \\
(1.909)\end{array}$ & $\begin{array}{c}0.020 * * \\
(2.446)\end{array}$ & $\begin{array}{c}0.017 \\
(1.577)\end{array}$ & $\begin{array}{c}0.015 \\
(0.847)\end{array}$ & $\begin{array}{c}0.028 \\
(1.157)\end{array}$ \\
\hline OWN_CONT & $\begin{array}{c}0.021 * * \\
(2.107)\end{array}$ & $\begin{array}{c}0.020 * * * \\
(2.729)\end{array}$ & $\begin{array}{c}0.005 \\
(0.681)\end{array}$ & $\begin{array}{c}0.005 \\
(0.594)\end{array}$ & $\begin{array}{c}-0.033 * * \\
(-2.086)\end{array}$ & $\begin{array}{c}-0.016 \\
(-0.784)\end{array}$ \\
\hline TRNVOL & $\begin{array}{l}1.843 * * \\
(2.034)\end{array}$ & $\begin{array}{c}1.109 \\
(1.622)\end{array}$ & $\begin{array}{c}0.716 \\
(1.073)\end{array}$ & $\begin{array}{c}2.200 * * * \\
(2.599)\end{array}$ & $\begin{array}{c}5.388 * * * \\
(3.655)\end{array}$ & $\begin{array}{c}5.722 * * * \\
(2.937)\end{array}$ \\
\hline BLOCK & $\begin{array}{c}0.022 \\
(1.497)\end{array}$ & $\begin{array}{l}0.020 * \\
(1.783)\end{array}$ & $\begin{array}{c}0.005 \\
(0.451)\end{array}$ & $\begin{array}{c}-0.002 \\
(-0.131)\end{array}$ & $\begin{array}{c}-0.022 \\
(-0.905)\end{array}$ & $\begin{array}{c}-0.004 \\
(-0.130)\end{array}$ \\
\hline OWNCONC & $\begin{array}{c}-0.011 \\
(-0.509)\end{array}$ & $\begin{array}{c}-0.015 \\
(-0.890)\end{array}$ & $\begin{array}{c}-0.023 \\
(-1.390)\end{array}$ & $\begin{array}{c}-0.021 \\
(-1.039)\end{array}$ & $\begin{array}{c}-0.137 * * * \\
(-3.661)\end{array}$ & $\begin{array}{c}-0.159 * * * \\
(-3.336)\end{array}$ \\
\hline LNCAP & $\begin{array}{c}-0.001 \\
(-0.244)\end{array}$ & $\begin{array}{c}-0.001 \\
(-0.697)\end{array}$ & $\begin{array}{c}-0.004 * * \\
(-2.138)\end{array}$ & $\begin{array}{c}-0.007 * * * \\
(-2.755)\end{array}$ & $\begin{array}{c}-0.014 * * * \\
(-3.158)\end{array}$ & $\begin{array}{c}-0.018 * * * \\
(-3.314)\end{array}$ \\
\hline LNMBV & $\begin{array}{l}-0.007 * * \\
(-2.411)\end{array}$ & $\begin{array}{c}-0.006 * * * \\
(-2.702)\end{array}$ & $\begin{array}{c}-0.006 * * \\
(-2.423)\end{array}$ & $\begin{array}{c}-0.011 * * * \\
(-3.804)\end{array}$ & $\begin{array}{l}-0.008 * \\
(-1.652)\end{array}$ & $\begin{array}{c}-0.017 * * \\
(-2.725)\end{array}$ \\
\hline LNTABV & $\begin{array}{c}0.023 * * * \\
(3.113) \\
\end{array}$ & $\begin{array}{c}0.016 * * * \\
(2.883) \\
\end{array}$ & $\begin{array}{c}0.003 \\
(0.620) \\
\end{array}$ & $\begin{array}{c}0.006 \\
(0.859) \\
\end{array}$ & $\begin{array}{c}-0.017 \\
(-1.432) \\
\end{array}$ & $\begin{array}{c}-0.007 \\
(-0.446) \\
\end{array}$ \\
\hline $\mathrm{R}^{2}$ & $5.30 \%$ & $6.30 \%$ & $3.50 \%$ & $5.30 \%$ & $9.20 \%$ & $7.40 \%$ \\
\hline Adjusted $\mathrm{R}^{2}$ & $3.40 \%$ & $4.40 \%$ & $1.50 \%$ & $3.30 \%$ & $7.40 \%$ & $5.50 \%$ \\
\hline Avg VIF & 2.153 & 2.153 & 2.153 & 2.153 & 2.153 & 2.153 \\
\hline F-statistic & 2.726 & 3.264 & 1.743 & 2.708 & 4.943 & 3.881 \\
\hline
\end{tabular}

Note. Values in brackets are t statistics. *,**,*** indicates statistical significance of $10 \%, 5 \%$ and $1 \%$ respectively.

On the other hand, examining the sales announcements, we find little evidence to support a relationship between the position held by the insider within the firm and abnormal returns. In the case where transactions are performed by non-executive members of the board CARs are influenced negatively for the event window of $(-2,0),(0,+1)(0,+2)$ by $(0,+20)$ by $-0.017,-0.016,-0.020$ and -0.053 respectively, whereas no relationship is found for CEO and member of the Board of Directors. Separation of ownership and control does not seem to play an important role either, as results indicate that when the CEO is also the main shareholder of the firm there is a positive (negative) and statistically significant impact on abnormal returns in the case of purchases (sales) announcements only two days and one day before the announcement, providing some support for the information hypothesis.

The existence of a blockholder has no effect on CARs in the case of buying transactions and negative effect in the case of sales transactions announcements. Ownership concentration has a negative effect in purchases for the event windows $(0,+10),(0,+20)-0.137$ and -0.159 respectively, but as far as sales are concerned, the effect on abnormal returns is positive and more specifically equals to $+0.078,+0.186 \kappa \alpha \mathrm{l}+0.239$ for the $(0,+2),(0,+10)$, and $(0,+20)$ periods, respectively.

The transactions' volume has a systematically positive effect on purchases transactions, and a negative one on sales, but in the second case, this effect is only significant for the $(0,+20)$ period of time. Finally, the financial control variables were found to have a negative effect on both samples, but this impact was not statistically significant for all the event windows we have examined. 
Table 4. OLS results for sales announcements (138 observations)

\begin{tabular}{|c|c|c|c|c|c|c|}
\hline & $\begin{array}{l}\text { CAR } \\
(-2,0) \\
\end{array}$ & $\begin{array}{l}\text { CAR } \\
(-1,0) \\
\end{array}$ & $\begin{array}{c}\text { CAR } \\
(0,+1) \\
\end{array}$ & $\begin{array}{c}\text { CAR } \\
(0,+2) \\
\end{array}$ & $\begin{array}{l}\text { CAR } \\
(0,+10) \\
\end{array}$ & $\begin{array}{c}\text { CAR } \\
(0,+20) \\
\end{array}$ \\
\hline \multirow[t]{2}{*}{ Constant } & 0.044 & 0.048 & 0.056 & 0.106 & -0.028 & $-0.352 *$ \\
\hline & $(0.483)$ & $(0.590)$ & $(0.656)$ & $(1.015)$ & $(-0.167)$ & $(-1.667)$ \\
\hline \multirow[t]{2}{*}{ CEO } & 0.004 & 0.014 & -0.007 & 0.002 & 0.004 & 0.020 \\
\hline & $(0.440)$ & (1.622) & $(-0.826)$ & $(0.188)$ & $(0.227)$ & $(0.918)$ \\
\hline \multirow[t]{2}{*}{ BOD_MEM } & $0.018 *$ & 0.015 & 0.015 & 0.012 & 0.004 & 0.012 \\
\hline & (1.730) & $(1.585)$ & $(1.522)$ & $(0.989)$ & $(0.181)$ & $(0.501)$ \\
\hline \multirow[t]{2}{*}{ BOD_NXC } & $-0.017 *$ & -0.011 & $-0.016^{*}$ & $-0.020 *$ & -0.017 & $-0.053 * *$ \\
\hline & $(-1.772)$ & $(-1.240)$ & $(-1.696)$ & $(-1.809)$ & $(-0.916)$ & $(-2.338)$ \\
\hline \multirow[t]{2}{*}{ OWN_CONT } & $-0.026 * *$ & $-0.026 * * *$ & -0.007 & -0.011 & $0.036^{*}$ & 0.007 \\
\hline & $(-2.604)$ & $(-2.961)$ & $(-0.704)$ & $(-0.998)$ & (1.949) & $(0.306)$ \\
\hline \multirow[t]{2}{*}{ TRNVOL } & -0.085 & -0.063 & -0.246 & 0.311 & -0.661 & $-2.347 * * *$ \\
\hline & $(-0.243)$ & $(-0.202)$ & $(-0.752)$ & $(0.773)$ & $(-1.020)$ & $(-2.891)$ \\
\hline \multirow[t]{2}{*}{ BLOCK } & $0.063^{*}$ & 0.009 & -0.011 & -0.050 & $-0.158 * *$ & 0.074 \\
\hline & (1.703) & $(0.284)$ & $(-0.321)$ & $(-1.173)$ & $(-2.287)$ & $(0.855)$ \\
\hline \multirow[t]{2}{*}{ OWNCONC } & -0.015 & 0.047 & 0.055 & $0.078^{*}$ & $0.186^{* * *}$ & $0.239 * * *$ \\
\hline & $(-0.393)$ & (1.405) & $(1.560)$ & (1.793) & $(2.659)$ & (2.717) \\
\hline \multirow[t]{2}{*}{ LNCAP } & -0.004 & -0.005 & -0.005 & -0.008 & -0.001 & 0.007 \\
\hline & $(-1.053)$ & $(-1.407)$ & $(-1.303)$ & $(-1.617)$ & $(-0.150)$ & $(0.785)$ \\
\hline \multirow[t]{2}{*}{ LNMBV } & 0.000 & -0.002 & $-0.011^{* * *}$ & $-0.016^{* * *}$ & $-0.026 * * *$ & -0.016 \\
\hline & $(0.023)$ & $(-0.537)$ & $(-2.332)$ & $(-2.731)$ & $(-2.786)$ & $(-1.359)$ \\
\hline \multirow[t]{2}{*}{ LNTABV } & $0.033 * * *$ & $0.029 * * *$ & -0.002 & -0.004 & $-0.055 * * *$ & 0.030 \\
\hline & (3.775) & (3.671) & $(-0.254)$ & $(-0.424)$ & $(-3.341)$ & (1.479) \\
\hline $\mathrm{R}^{2}$ & $19.20 \%$ & $22.10 \%$ & $13.90 \%$ & $16.30 \%$ & $18.00 \%$ & $23.30 \%$ \\
\hline Adjusted $\mathrm{R}^{2}$ & $12.80 \%$ & $13.90 \%$ & $7.10 \%$ & $9.70 \%$ & $11.60 \%$ & $17.30 \%$ \\
\hline Avg VIF & 4.184 & 4.184 & 4.184 & 4.184 & 4.184 & 4.184 \\
\hline F-statistic & 3.009 & 3.594 & 2.047 & 2.474 & 2.795 & 3.877 \\
\hline
\end{tabular}

Note. Values in brackets are t statistics. *,**,*** indicates statistical significance of $10 \%, 5 \%$ and $1 \%$ respectively.

In Table 5 the results for the combined sample of transactions are presented. Transactions are important when being performed by the CEO (positive) and executive members of the board (negative) only in the long term period after the transaction, namely $(0,+10)$ and $(0,+20)$. Transactions made by the CEO when he is the blockholder at the same time is only statistically important in one event window $(0,+10)$. Ownership by the biggest blockholder, affects abnormal returns positively only in the short term prior to the transactions, in the stock price support rationale, and does not have any statistical impact after the announcement. The large shareholders, on the other hand, have a negative and statistically significant impact on the long term CARs, that may be explained by the overall negative outlook of the market. Considering these results with the ones provided by table 3 can provide evidence for the existence of a relationship between insider trading and ownership structure. The Chow test rejects the hypothesis of structural stability between the purchases and sales for the long term periods of time, $(0,+10)$ and $(0,+20)$ after the transaction announcement occurs. In short term periods prior and after the sales and purchases model seems to be structural stable. That result, taken under consideration with the results of the regressions for sales and purchases, offer evidence for the liquidity motivation hypothesis of insider trading (Hamill et al., 2002), and provides partial support for our hypothesis on the structural stability of insider trading patterns of sales and purchases.

In terms of robustness check, some evidence of heteroscedasticity and multicollinearity has been detected. When testing for heteroscedasticity according to White, and correcting the influence, by estimating the heteroscedasticity-consistent covariance matrix estimator, our model has not provided any different results in terms of economic rationale, and explanatory power or statistical significance of the variables employed. Average Variance Inflating Factor (VIF) did not reveal any extreme multicollinearity issues, with the exception of the regression concerning sales where despite the fact that average VIF is significantly less than 10, the VIF test for one variable of the model hint on the possibility of existing multicollinearity. These issues, however, should be attributed to the small size of the sales sub-sample, the characteristics of cross-sectional data (Gujarati, 2004; Fidrmuc et al., 2006; Leledakis et al., 2010), and the differences in the financial characteristics of the firms. 
Table 5. OLS results for the pooled sample - Chow tests (636 observations)

\begin{tabular}{|c|c|c|c|c|c|c|}
\hline & $\begin{array}{l}\text { CAR } \\
(-2,0) \\
\end{array}$ & $\begin{array}{l}\text { CAR } \\
(-1,0) \\
\end{array}$ & $\begin{array}{l}\text { CAR } \\
(0,+1) \\
\end{array}$ & $\begin{array}{l}\text { CAR } \\
(0,+2)\end{array}$ & $\begin{array}{c}\text { CAR } \\
(0,+10) \\
\end{array}$ & $\begin{array}{c}\text { CAR } \\
(0,+20)\end{array}$ \\
\hline Constant & $\begin{array}{c}-0.038 \\
(-0.829)\end{array}$ & $\begin{array}{c}-0.015 \\
(-0.434)\end{array}$ & $\begin{array}{c}0.063 \\
(1.831)\end{array}$ & $\begin{array}{l}0.111 * * \\
(2.546)\end{array}$ & $\begin{array}{c}0.320 * * * \\
(4.162)\end{array}$ & $\begin{array}{c}0.326 * * * \\
(3.234)\end{array}$ \\
\hline CEO & $\begin{array}{c}0.004 \\
(0.561)\end{array}$ & $\begin{array}{c}0.002 \\
(0.293)\end{array}$ & $\begin{array}{c}0.002 \\
(0.417)\end{array}$ & $\begin{array}{c}0.004 \\
(0.506)\end{array}$ & $\begin{array}{c}0.025 * * \\
(\mathbf{2 . 0 3 2})\end{array}$ & $\begin{array}{c}0.034 * * \\
(2.095)\end{array}$ \\
\hline BOD_MEM & $\begin{array}{c}0.009 \\
(0.992)\end{array}$ & $\begin{array}{c}0.010 \\
(1.580)\end{array}$ & $\begin{array}{c}0.003 \\
(0.474)\end{array}$ & $\begin{array}{c}-0.001 \\
(-0.151)\end{array}$ & $\begin{array}{l}-0.030 * * \\
(-2.057)\end{array}$ & $\begin{array}{c}-0.034 * \\
(-1.811)\end{array}$ \\
\hline BOD_NXC & $\begin{array}{c}0.006 \\
(0.846)\end{array}$ & $\begin{array}{c}0.007 \\
(1.171)\end{array}$ & $\begin{array}{c}0.008 \\
(1.413)\end{array}$ & $\begin{array}{c}0.005 \\
(0.704)\end{array}$ & $\begin{array}{c}0.013 \\
(1.023)\end{array}$ & $\begin{array}{c}0.013 \\
(0.792)\end{array}$ \\
\hline OWN_CONT & $\begin{array}{c}0.009 \\
(1.255)\end{array}$ & $\begin{array}{c}0.007 \\
(1.312)\end{array}$ & $\begin{array}{c}-0.001 \\
(-0.155)\end{array}$ & $\begin{array}{c}-0.003 \\
(-0.470)\end{array}$ & $\begin{array}{l}-0.022 * \\
(-1.855)\end{array}$ & $\begin{array}{c}-0.018 \\
(-1.139)\end{array}$ \\
\hline TRNVOL & $\begin{array}{c}0.556 \\
(1.276)\end{array}$ & $\begin{array}{c}0.479 \\
(1.427)\end{array}$ & $\begin{array}{c}0.181 \\
(0.551)\end{array}$ & $\begin{array}{c}1.021 * * \\
(2.466)\end{array}$ & $\begin{array}{l}1.239 * \\
(1.706)\end{array}$ & $\begin{array}{c}0.179 \\
(0.188)\end{array}$ \\
\hline BLOCK & $\begin{array}{c}0.031 * * \\
(2.416)\end{array}$ & $\begin{array}{c}0.027 * * * \\
(2.714)\end{array}$ & $\begin{array}{c}0.006 \\
(0.572)\end{array}$ & $\begin{array}{c}-0.002 \\
(-0.151)\end{array}$ & $\begin{array}{c}-0.026 \\
(-1.197)\end{array}$ & $\begin{array}{c}0.023 \\
(0.817)\end{array}$ \\
\hline OWNCONC & $\begin{array}{c}-0.011 \\
(-0.607)\end{array}$ & $\begin{array}{c}-0.008 \\
(-0.581)\end{array}$ & $\begin{array}{c}-0.016 \\
(-1.172)\end{array}$ & $\begin{array}{c}-0.017 \\
(-0.943)\end{array}$ & $\begin{array}{c}-0.116^{* * *} \\
(-3.734)\end{array}$ & $\begin{array}{c}-0.120 * * * \\
(-2.950)\end{array}$ \\
\hline LNCAP & $\begin{array}{c}0.000 \\
(-0.109)\end{array}$ & $\begin{array}{c}-0.001 \\
(-0.748)\end{array}$ & $\begin{array}{c}-0.004 * * \\
(-2.404)\end{array}$ & $\begin{array}{c}-0.006 * * * \\
(-3.177)\end{array}$ & $\begin{array}{c}-0.012 * * * \\
(-3.467)\end{array}$ & $\begin{array}{c}-0.015 * * * \\
(-3.212)\end{array}$ \\
\hline LNMBV & $\begin{array}{l}-0.006 * * \\
(-2.412)\end{array}$ & $\begin{array}{c}-0.006 * * * \\
(-2.863)\end{array}$ & $\begin{array}{c}-0.007 * * * \\
(-3.378)\end{array}$ & $\begin{array}{c}-0.012 * * * \\
(-4.685)\end{array}$ & $\begin{array}{l}-0.009 * * \\
(-2.122)\end{array}$ & $\begin{array}{c}-0.015 * * * \\
(-2.661)\end{array}$ \\
\hline LNTABV & $\begin{array}{c}0.025 * * * \\
(3.988)\end{array}$ & $\begin{array}{c}0.018 * * * \\
(3.688)\end{array}$ & $\begin{array}{c}0.002 \\
(0.409)\end{array}$ & $\begin{array}{c}0.004 \\
(0.723)\end{array}$ & $\begin{array}{l}-0.019 * \\
(-1.834)\end{array}$ & $\begin{array}{c}0.006 \\
(0.410)\end{array}$ \\
\hline $\mathrm{R} 2$ & $4.16 \%$ & $4.84 \%$ & $2.77 \%$ & $4.82 \%$ & $5.56 \%$ & $4.98 \%$ \\
\hline Adjusted R2 & $2.62 \%$ & $3.32 \%$ & $1.21 \%$ & $3.29 \%$ & $4.05 \%$ & $3.46 \%$ \\
\hline Avg VIF & 2.363 & 2.363 & 2.363 & 2.363 & 2.363 & 2.363 \\
\hline Chow Test & 1.431 & $2.270 * *$ & 1.340 & 1.243 & $3.282 * * *$ & $3.057 * * *$ \\
\hline F-statistic & 2.711 & 3.178 & 1.778 & 3.163 & 3.681 & 3.278 \\
\hline
\end{tabular}

Note. Values in brackets are t statistics. ${ }^{*}, * *, * * *$ indicate statistical significance of $10 \%, 5 \%$ and $1 \%$ respectively.

\section{Conclusions}

In this paper, we have assessed the relationship between abnormal returns of stock prices following insider trading announcement, ownership structure, and corporate governance mechanisms, the position the insider holds within the firms, and control variables describing the financial characteristics of the firm. We have focused on the firms of the Greek technology sector in the Athens stock exchange market, for the period between 2007 and 2013 that is characterized by great changes and an unprecedented crisis in the Greek economy and stock market.

Our results provide interesting issues for discussion. Despite the fact that there is some evidence on the presence of a relationship between insider trading and corporate governance mechanisms through ownership structure, the results are inconclusive. Our findings are in line with the ones provided by the literature, such as the ones of Dickgiesser and Kaserer (2009) and Gregory et al. (2009), as there is evidence on the effect that insiders' transaction has on abnormal stock returns, but this effect is neither clear nor uniform. Our results concur with relevant theory as investors and outsiders, consider the information advantage held by the CEO and other executives (Fidrmuc et al., 2006) particularly in the case of transactions regarding stock purchases in companies where the CEO is not the main blockholder of the firm, indicating the existence of agency problem.

Our results are also inconclusive concerning the fashion that ownership structure influences abnormal returns produced by insider trading. A negative (positive) relationship for purchasing (selling) announcements were identified, but the pattern is not conclusive and describes only long-term periods of time (event windows) after the announcement of the transaction. There is also the possibility that investors evaluate negatively the concentration of ownership and control in the hands of the CEO that is contrary to the findings of Adams et al. (2005). The rationale for this reaction, however, may also lie in the overall negative outlook of the market, due to the Greek financial crisis. 
Finally, structural stability tests indicated that there are different patterns of insider trading between sales and purchases but only for long term periods after the transaction. The examination of a bigger sample of announcements, that would include other industries as well, and would focus on the transactions performed solely by the executive members of the Board, could provide more conclusive results on this relationship. The interpretation of the above findings should also take under consideration the examined period, where the unfavorable economic environment influenced heavily the Greek Stock market and the way the firms examined operated (Antoniadis et al., 2019). That adverse economic and financial environment could lead insiders of Greek firms to execute transactions for reasons other than the ones suggested by the relevant literature (Hamill et al., 2002; Antoniadis et al., 2019).

Further research could contribute to clarifying the linkage between corporate governance and insider trading, especially in a stock market with the characteristics of the Greek one. First of all, research should focus on examining whether there are different patterns of insider trading before the Greek Financial Crisis and afterward. A more detailed examination of other corporate governance mechanisms, like for example a detailed examination of the composition of the Board of Directors, and the committees that operate in the firm (audit, remuneration committee, etc.), would provide useful insight in the matter. Since there have been changes in the legal framework of insider trading as of 2016 in the Greek stock market, a comparison of insider trading patterns and the effect that legislation had would also provide useful and applicable insights on the matter.

An important limitation of the present study was also a small sample of announcements, especially in terms of sales. Expanding the research sample to the whole market and to other sectors and industries individually would help address methodological and econometric problems, and provide insight, to whether there are differences of insider trading patterns across different industries. A multi-industry research like that would significantly help both investors and regulators to understand the factors affecting insider trading behavior, understanding that would prove fruitful especially in periods of financial crises and would contribute to the ongoing research and literature on insider trading, corporate governance and the efficient market hypothesis.

\section{References}

Adams, R. B., Almeida, H., \& Ferreira, D. (2005). Powerful CEOs and Their Impact on Corporate Performance. Review of Financial Studies, Society for Financial Studies, 18(4), 1403-1432. https://doi.org/10.1093/rfs/hhi030

Agrawal, A., \& Knoeber, C. R. (1996). Firm performance and mechanisms to control agency problems between managers and shareholders. Journal of financial and quantitative analysis, 31(03), 377-397. https://doi.org/10.2307/2331397

Alimehmeti, G., \& Paletta, A. (2012). Ownership Concentration and Effects over Firm Performance: Evidence from Italy. European Scientific Journal, 8(22), 39-49.

Antoniadis, I., Gkasis, C., \& Kontsas, S. (2017). Corporate Governance, Insider Trading, and Stock Returns in the Greek Technology Sector. In Advances in Applied Economic Research (pp. 679-690). Springer, Cham. https://doi.org/10.1007/978-3-319-48454-9_46

Antoniadis, I., Gkasis, C., \& Partalidou, X. (2019). Insider Trading Patterns in Periods of Financial Crisis: A Study of the Technological Sector of Athens Stock Exchange Market. International Journal of Economics and Financial Issues, 9(2), 241-250. https://doi.org/10.32479/ijefi.7635

Antoniadis, I., Gkasis, C., \& Sormas, A. (2015). Insider trading and stock market prices in the Greek technology sector. Procedia Economics and Finance, 24, 60-67. https://doi.org/10.1016/S2212-5671(15)00612-7

Arshadi, N., \& Eyssell, T. H. (1995). Recent on Corporate Governance: Public Corporations, Corporate Takeovers, Defensive Tactics, and Insider Trading., Financial Markets, Institutions, and Instruments, 4, 74-103.

Bailey, W., Karolyi, G. A., \& Salva, C. (2006). The economic consequences of increased disclosure: Evidence from international cross-listings. Journal of Financial Economics, 81(1), 175-213. https://doi.org/10.1016/j.jfineco.2005.06.002

Bainbridge, S. M. (2000). Insider Trading, in Encyclopedia of Law and Economics III (pp. 772-812). Cheltenham, U.K.: Edward Elgar Publishing. http://dx.doi.org/10.4337/9781784713973

Bajo, E., Bigelli, M., Hillier, D., \& Petracci, B. (2009). The determinants of regulatory compliance: An analysis of insider trading disclosures in Italy. Journal of Business Ethics, 90(3), 331. https://doi.org/10.1007/s10551-009-0044-x 
Baryeh, L., DaDalt, P. \& Yaari, V. (2009). Insider trading by directors and seniors officers before seasoned equity offerings. Corporate Ownership \& Control, 7(2-3), 258-266. https://doi.org/10.22495/cocv7i2c3p3

Bebchuk, L. A., \& Weisbach, M. S. (2010). The state of corporate governance research. Review of Financial Studies, 23(3), 939-961. https://doi.org/10.1093/rfs/hhp121

Beny, L. N. (2004). A Comparative Empirical Investigation of Agency and Market Theories of Insider Trading. Ann Arbor, 1001, 48109. https://doi.org/10.2139/ssrn.193070

Beny, L. N. (2006). Insider trading laws and stock markets around the world: An empirical contribution to the theoretical law and economics debate. Journal of Corporation Law, 32, 237.

Betzer, A., \& Theissen, E. (2009). Insider trading and corporate governance: The case of Germany. European Financial Management, 15(2), 402-429. https://doi.org/10.1111/j.1468-036X.2007.00422.x

Bhide, A. (1993). The hidden costs of stock market liquidity. Journal of Financial Economics, 34, 31-51. https://doi.org/10.1016/0304-405X(93)90039-E

Brooks, C. (2008). Introductory econometrics for finance (2nd ed.). Cambridge University Press. https://doi.org/10.1017/9781108524872

Brown, S. J., \& Warner, J. B. (1985). Using daily stock returns: The case of event studies. Journal of Financial Economics, 14(1), 3-31. https://doi.org/10.1016/0304-405X(85)90042-X

Bushman, R. M., \& Smith, A. J. (2003). Transparency, financial accounting information, and corporate governance. Financial Accounting Information, and Corporate Governance. Economic Policy Review, 9(1), 65-87. https://doi.org/10.2139/ssrn.253302

Campbell, J. Y., Lo, A. W. C., \& MacKinlay, A. C. (1997). The econometrics of financial markets. Princeton, NJ: Princeton University Press. https://doi.org/10.2307/j.ctt7skm5

Cinar, E. M. (1999). The issue of insider trading in law and economics: Lessons for emerging financial markets in the world. Journal of Business Ethics, 19(4), 345-353. https://doi.org/10.1023/A:1005913602588

Cziraki, P., de Goeij, P. C., \& Renneboog, L. D. R. (2014). Corporate governance rules and insider trading profits. Review of Finance, 18(1), 67-108. https://doi.org/10.1093/rof/rft001

Dai, L., Fu, R., Kang, J. K., \& Lee, I. (2013). Internal corporate governance and insider trading. Work. Pap., Erasmus Univ. https://doi.org/10.2139/ssrn.2022887

Demsetz, H., \& Villalonga, B. (2001). Ownership structure and corporate performance. Journal of Corporate Finance, 7(3), 209-233. https://doi.org/10.1016/S0929-1199(01)00020-7

Dhaliwal, D. S., Heitzman, S., \& Zhen Li, O. (2006). Taxes, leverage, and the cost of equity capital. Journal of Accounting Research, 44(4), 691-723. https://doi.org/10.1111/j.1475-679X.2006.00214.X

Dickgiesser, S., \& Kaserer, C. (2009). Market Efficiency Reloaded: Why Insider Trades Do Not Reveal Exploitable Information. German Economic Review, 11(3), 302-335. https://doi.org/10.1111/j.1468-0475.2009.00476.x

Du, J., \& Wei, S. J. (2004). Does insider trading raise market volatility? The Economic Journal, 114(498), 916-942. https://doi.org/10.1111/j.1468-0297.2004.00249.x

Enriques, L., \& Volpin, P. (2007). Corporate governance reforms in continental Europe. The Journal of Economic Perspectives, 21(1), 117-140. https://doi.org/10.1257/jep.21.1.117

Fama, E. F., \& French, K. R. (1992). The cross - section of expected stock returns. The Journal of Finance, 47(2), 427-465. https://doi.org/10.1111/j.1540-6261.1992.tb04398.x

Fidrmuc, Jana P., Goergen, M., \& Renneboog, L. (2006). Insider Trading, News Releases, and Ownership Concentration. The Journal of Finance, 61(6), 2931-2973. https://doi.org/10.1111/j.1540-6261.2006.01008.x

Goergen, M., \& Renneboog, L. (2006). Corporate governance and shareholder value. Commercial Management of Projects: Defining the Discipline, 100-131. https://doi.org/10.1002/9780470759509.ch5

Greene, W. H. (2000). Econometric analysis (4th ed.). New Jersey: Prentice Hall.

Gregory, A., Tharyan, R., \& Tonks, I. (2009). Stock market patterns around directors'trades: Effects of director category and gender on market timing. Working Paper, University of Exeter Business School. https://doi.org/10.2139/ssrn.1433716 
Gujarati, D. (2004). Basic Econometrics (4th ed.). McGraw-Hill.

Hamill, P. A., McIlkenny, P., Kwaku, \& Opong, K. (2002). Directors' Share Dealings and Company Financial Performance. Journal of Management and Governance, (6), 215-234. https://doi.org/10.1023/A:1019677230611

He, Q., \& Rui, O. M. (2016). Ownership structure and insider trading: Evidence from China. Journal of Business Ethics, 134(4), 553-574. https://doi.org/10.1007/s10551-014-2384-4

Hu, J., \& Noe, T. H. (2001). Insider trading and managerial incentives. Journal of Banking \& Finance, 25(4), 681-716. https://doi.org/10.1016/S0378-4266(00)00098-4

Jackson, D., Dutta, S., \& Nitani, M. (2008). Corporate governance and informed trading. International Journal of Managerial Finance, 4(4), 295-322. https://doi.org/10.1108/17439130810902804

Jeng, L. A., Metrick, A., \& Zeckhauser, R. (2003). Estimating the returns to insider trading: A performance-evaluation perspective. Review of Economics and Statistics, 85(2), 453-471. https://doi.org/10.1162/003465303765299936

Jiraporn, P., Kim, J. C., Kim, Y. S., \& Kitsabunnarat, P. (2012). Capital structure and corporate governance quality: Evidence from the Institutional Shareholder Services (ISS). International Review of Economics \& Finance, 22(1), 208-221. https://doi.org/10.1016/j.iref.2011.10.014

Kapopoulos, P., \& Lazaretou, S. (2007). Corporate ownership structure and firm performance: Evidence from Greek firms. Corporate Governance: An International Review, 15(2), 144-158. https://doi.org/10.1111/j.1467-8683.2007.00551.x

Kennedy, P. (2008). A guide to econometrics $\left(6^{\text {th }}\right.$ ed). Willey-Blackwell.

Kostyuk, A., Mozghovyi, Y., \& Govorun, D. (2018). Corporate governance, ownership, and control: A review of recent scholarly research. Corporate Board: Role, Duties and Composition, 14(1), 50-56. https://doi.org/10.22495/cbv14i1art4

Koudijs, P. (2015). Those who know most: Insider trading in eighteenth-century Amsterdam. Journal of Political Economy, 123(6), 1356-1409. https://doi.org/10.1086/683839

La Porta, R., Lopez-de-Silanes, F., Shleifer, A., \& Vishny, R. (2002). Investor protection and corporate valuation. The Journal of Finance, 57(3), 1147-1170. https://doi.org/10.1111/1540-6261.00457

Lambe, B. (2012). Is insider trading regulation effective? Evidence from UK takeover activity. Journal of Governance and Regulation, 1(2), 24-48. https://doi.org/10.22495/jgr_v1_i2_p2

Langenbucher, K. (2014). Insider Trading in European Law. In M. Stephen (Ed.), Research Handbook on Insider Trading (pp. 429-448). Bainbridge, Cheltenham, Massachusetts. https://doi.org/10.4337/9780857931856.00035

Law 3340/2005. For the protection of Capital from actions of persons that possess inside information and market manipulation. Retrieved from http://www.hcmc.gr/en_US/web/portal/elib/lawslaws

Lekkas, P. (1998). Insider Trading and the Greek Stock Market. Business Ethics: A European Review, 7(4), 193-199. https://doi.org/10.1111/1467-8608.00107

Leland, H. E. (1992). Insider trading: Should it be prohibited?. Journal of Political Economy, 100(4), 859-887. https://doi.org/10.1086/261843

Leledakis, G. N., Efthymiou, V. A., Kontopoulou, K., \& Nerantzidis M. (2010). Insider Trading and Ownership Structure: Evidence from the Athens Stock Exchange. In E. Tzavalis (Ed.), Studies in the Greek Financial System. Athens University of Economics and Business Press.

Lizarzaburu, B. E., Berggrun, L., \& Burneo, K. (2014). Corporate governance in emerging markets and its impact on finance performance. Corporate Ownership \& Control, 12(1-7), 625-632. https://doi.org/10.22495/cocv12i1c7p2

Maug, E. (2002). Insider trading legislation and corporate governance. European Economic Review, 46(9), 1569-1597. https://doi.org/10.1016/S0014-2921(02)00243-X

McKinlay, A. C. (1997). Event Studies in Economics and Finance. Journal of Economic Literature, 35(1), 13-39.

Moore, J. (1990). What is really unethical about insider trading? Journal of Business Ethics, 9(3), 171-182. https://doi.org/10.1007/BF00382642 
Morck, R., Nakamura, M., \& Shivdasani, A. (2000). Banks, ownership structure, and firm value in Japan. The Journal of Business, 73(4), 539-567. https://doi.org/10.1086/209654

Nerantzidis, M., \& Filos, J. (2014). Recent corporate governance developments in Greece. Corporate Governance, 14(3), 281-299. https://doi.org/10.1108/CG-10-2011-0080

Nerantzidis, M., \& Tsamis, A. (2017). Going back to go forward: On studying the determinants of corporate governance disclosure. Corporate Governance: The International Journal of Business in Society, 17(3), 365-402. https://doi.org/10.1108/CG-07-2016-0145

Nwafor, A. O. (2015). Transparency in corporate governance: Extent of directors' duty to declare interest in company's transactions. Corporate board: Role, duties and Composition, 11(1), 137-148. https://doi.org/10.22495/cbv11i1c1art6

Penman, S. H., Richardson, S. A., \& Tuna, I. (2007). The book-to-price effect in stock returns: Accounting for leverage. Journal of Accounting Research, 45(2), 467. https://doi.org/10.1111/j.1475-679X.2007.00240.x

Ravina, E., \& Sapienza, P. (2009). What do independent directors know? Evidence from their trading. The Review of Financial Studies, 23(3), 962-1003. https://doi.org/10.1093/rfs/hhp027

SEC. (2017). Insider Trading. Retrieved from https://www.sec.gov/answers/insider.htm

Seyhun, H. N. (1986). Insiders' profits, costs of trading, and market efficiency. Journal of financial Economics, 16(2), 189-212. https://doi.org/10.1016/0304-405X(86)90060-7

Shleifer, A., \& Vishny, R. W. (1997). A survey of corporate governance. The Journal of Finance, 52(2), 737-783. https://doi.org/10.1111/j.1540-6261.1997.tb04820.x

Spanos, L. J. (2005). Corporate governance in Greece: Developments and policy implications. Corporate Governance: The international journal of business in society, 5(1), 15-30. https://doi.org/10.1108/14720700510583430

Thalassinos, E., Maditinos, D., \& Paschalidis, A. (2012). Observing evidence of insider trading in the Athens Stock Exchange. Journal of Economic Structures, 1(1), 1-26. https://doi.org/10.1186/2193-2409-1-8

Thomsen, S., \& Pedersen, T. (2000). Ownership structure and economic performance in the largest European $\begin{array}{lllll}\text { companies. } & \text { Strategic }\end{array}$ https://doi.org/10.1002/(SICI)1097-0266(200006)21:6\%3C689::AID-SMJ115\%3E3.0.CO;2-Y

Travlos, N. (2001). The development of systems of corporate governance in capital markets. Taseis - The Greek Economy, 170-182.

Von Koch, C., Nilsson, O., Jönsson, M., Andersson, J., \& Matthiesen, E. (2013). The impact of firm-level shareholder protections on abnormal returns on insider trading. Journal of Business and Financial Affairs, 3(1). https://doi.org/10.4172/2167-0234.1000114

\section{Copyrights}

Copyright for this article is retained by the author(s), with first publication rights granted to the journal.

This is an open-access article distributed under the terms and conditions of the Creative Commons Attribution license (http://creativecommons.org/licenses/by/4.0/). 